\title{
Prostaglandin H synthases, nonsteroidal anti- inflammatory drugs, and colon cancer
}

\author{
GERALD N. LEVY ${ }^{1}$ \\ Department of Pharmacology, University of Michigan, Ann Arbor, Michigan 48109-0632, USA
}

\begin{abstract}
Members of the structurally diverse class of drugs known as nonsteroidal anti-inflammatory drugs (NSAIDs) have the ability to prevent or reduce the occurrence of colorectal, certain other gastrointestinal, and perhaps other cancers. The anticarcinogenic property of NSAIDs has been shown in epidemiological studies with humans and in experimental carcinogenesis studies with animals. In addition, clinical studies of the human disease familial adenomatous polyposis have demonstrated the efficacy of NSAIDs in mediating regression of colorectal adenomas. The mechanism of the anticarcinogenic effect of these drugs is not known, but most hypotheses have involved the common property of the NSAIDs to inhibit prostaglandin synthase (PHS) enzymes and thereby cause a subsequent reduction in levels of prostaglandins (PG) in tissue. Recent reports have questioned the role of PHS inhibition in the anticarcinogenic activity of NSAIDs by showing that some NSAID-related compounds that are not PHS inhibitors can induce the same anticarcinogenic changes in cell cycle and apoptotic response as the PHS inhibitors. In this review we will examine the evidence that NSAIDs are anticarcinogenic, the evidence supporting PHS as the target of NSAIDs, and the evidence for and against inhibition of PG synthesis as the mechanism of cancer prevention by NSAIDs. - Levy, G. N. Prostaglandin H synthases, nonsteroidal anti-inflammatory drugs, and colon cancer. FASEB J. 11, 234-247 (1997)
\end{abstract}

Key Words: prostaglandin synthase $\cdot$ cyclooxygenase $\cdot$ cancer chemoprevention - apoptosis

\section{NSAIDs REDUCE THE RISK OF COLORECTAL CANCER IN HUMANS}

Epidemiologic observations of a reduction in the incidence of colon cancer in regular users of aspirin was reported in 1988 (1). This Australian study reported a 40-50\% reduction in colon cancer incidence among regular aspirin users. Most subsequent studies have reported similar findings (2-7). An exception to this trend is a study of elderly
Californians that showed a moderate increase in colon cancer among aspirin users (8).

The largest study of nonsteroidal anti-inflammatory drugs (NSAIDs) ${ }^{2}$ and colon cancer involves more than 600,000 individuals who were followed for fatal colon cancer and aspirin use (3). As in the other epidemiologic studies, quantitation of dose was imprecise but was estimated by ranking use into the categories of none, less than once, $1-15$, and 16 or more times per month. The rate of colon cancer death was inversely related to aspirin use in a dosedependent manner. The relative risk of fatal colon cancer for users of aspirin at $\mathbf{1 6}$ or more times per month was 0.60 for men and 0.58 for women. The relative risks did not change substantially after exclusion of individuals with preexisting disease at entry or after adjustment for other potential risk factors (3). In contrast to the results for aspirin use, no association of change in fatal colon cancer risk with acetaminophen use was found. Also in contrast to NSAIDs, steroidal anti-inflammatory drugs, which are known to inhibit expression of PHS-2 (9), did not decrease the risk of colon adenomas or adenocarcinomas (10).

Further follow-up and analysis of the population in this large study demonstrated a decreased death rate from cancers of the esophagus, stomach, and rectum in addition to that of colon among aspirin users (11). The reduction in risk of fatal digestive tract cancer among aspirin users was dose-dependent and the trend was strongest for persons who had used aspirin for 10 or more years. No consistent dose-response relationships were found between aspirin use and cancers outside the digestive tract.

\section{NSAIDs ARE ANTICARCINOGENIC IN ANIMALS}

In a wide variety of experimental systems NSAIDs including indomethacin, phenylbutazone, aspirin, piroxicam, ke-

\footnotetext{
' Correspondence: Department of Pharmacology, 1301 MSRB III, University of Michigan, Ann Arbor, MI 48109-0632, USA.

${ }^{2}$ Abbreviations: FANFT, N-(4-(5-nitro-2-furyl)-2-thiazolyl)-formamide; NSAIDs, nonsteroidal anti-inflammatory drugs; FAP, familial adenomatous polyposis; PHS, prostaglandin synthase; OH-BBN, N-butyl-N-(4-hydroxybutyl)nitrosamine; PG, prostaglandins; $\mathbf{P G I}_{2}$, prostacyclin; TXA $\mathrm{T}_{2}$, thromboxane $\mathrm{A}_{2}$; COX, cyclooxygenase; LOX, lipoxygenase; HPETEs, hydroperoxyeicosatetraenoic acids; HETEs, hydroxyeicosatetraenoic acids; MDA, malondialdehyde; RIE, rat intestinal epithelial cells; AF, 2-aminofluorene.
} 
toprofen, and sulindac have been shown to inhibit chemically induced tumors. A few examples are presented here. Esophageal tumors in mice treated with $\mathrm{N}$-nitrosodiethylamine were reduced by indomethacin administered either with the carcinogen or 4 months after exposure (12). Pancreatic tumors induced by $\mathrm{N}$-nitrosobis(2-oxopropyl)amine were reduced in hamsters receiving the prostaglandin synthase inhibitors indomethacin, phenylbutazone, or aspirin beginning $5 \mathrm{wk}$ after initiation of carcinogenesis (13). FANFT (N-(4-(5-nitro-2-furyl)-2thiazolyl)-formamide), a potent urinary bladder carcinogen in the rat, is activated in vitro by PHS. Aspirin treatment of rats exposed to FANFT for 12 wk showed a major reduction in the incidence of bladder cancer compared to FANFT-exposed but untreated rats (14). The effect of two NSAIDs, indomethacin and carprofen, on the enhancement of 7,12-dimethylbenz(a)anthracene-induced mammary carcinogenesis by dietary linoleate in rats was compared. Indomethacin had a marked inhibitory effect on the rats fed diets high in linoleate, but carprofen was not inhibitory at any fat level. Both NSAIDs reduced the level of $\mathrm{PGE}_{2}$, demonstrating that the inhibition of experimental mammary tumors in rats by these drugs does not correlate with decreases in PG levels (15). Thus, in this experimental system, reduction of PG levels and tumor inhibition are separable processes.

Differences between species in the effectiveness of various NSAIDs as chemopreventive agents have been shown to occur. N-butyl-N-(4-hydroxybutyl)nitrosamine (OH$\mathrm{BBN}$ ) induces rapidly growing and highly invasive transitional cell carcinomas of the bladder in male B6D2F1 mice. Sulindac and ketoprofen, but not aspirin, significantly reduced $\mathrm{OH}-\mathrm{BBN}$-induced bladder tumors in these mice as illustrated in Fig. 1 (16). In contrast, aspirin is effective in preventing $\mathrm{OH}-\mathrm{BBN}$-induced bladder tumors in rats, where the tumors resulting from $\mathrm{OH}-\mathrm{BBN}$ treatment are relatively slow-growing (17).

The most frequently studied tissue for the effect of NSAIDs on experimental carcinogenesis and the one with most relevance to human epidemiologic data is the intestinal tract. Pollard and Luckert (18) showed that indomethacin caused a $40 \%$ reduction in 1,2-dimethylhydrazine-induced intestinal tumors in rats. Narisawa et al. (19) demonstrated that rats exposed to methylnitrosourea developed colonic tumors that could be significantly lowered by indomethacin. However, in rats given the carcinogen and then indomethacin, cessation of treatment led to rapid development of tumors. Thus, indomethacin treatment inhibited the development of tumors but did not reject or kill the initiated cells. The influence of indomethacin and meclofenamate on the development of dimethylhydrazine-induced tumors in rats was examined by Metzger et al. (20). Colon cancer incidence was $56 \%$ in the carcinogen-exposed, indomethacin-treated animals, $90 \%$ in the carcinogen-exposed, meclofenamate-treated group, and $88 \%$ in the carcinogen-exposed, untreated controls. Piroxicam was shown to inhibit azoxymethane-induced colon cancer in rats in a dose-dependent manner
Prevention of Bladder Tumors in Mice

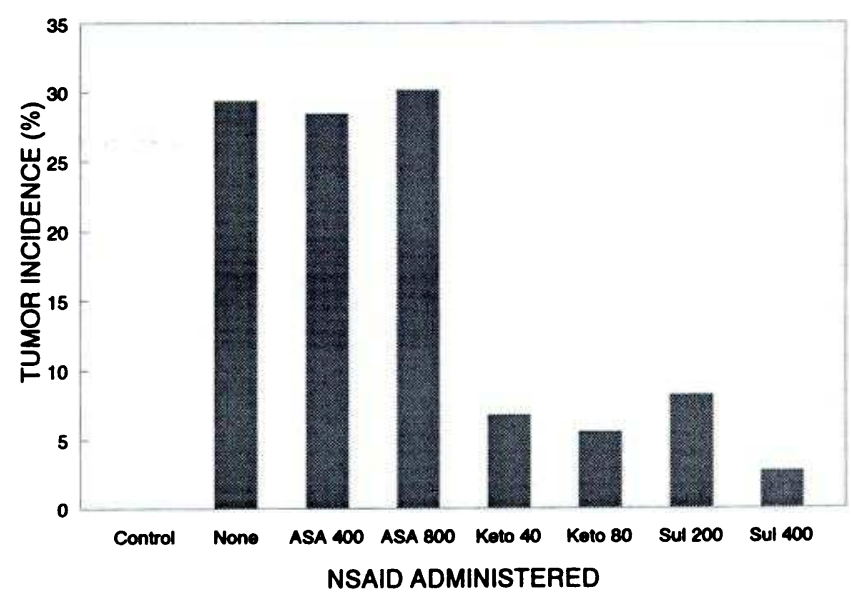

Figure 1. Inhibition of $\mathrm{OH}-\mathrm{BBN}$-induced bladder tumors in mice (16). Treatments: control: ASA $800 \mathrm{mg} / \mathrm{kg}$ diet or ketoprofen $80 \mathrm{mg} / \mathrm{kg}$ or sulindac $400 \mathrm{mg} / \mathrm{kg}$, no $\mathrm{OH}-\mathrm{BBN}$. None: $\mathrm{OH}-\mathrm{BBN}$ alone. ASA: $\mathrm{OH}-$ BBN plus aspirin 400 or $800 \mathrm{mg} / \mathrm{kg}$ diet. Keto: $\mathrm{OH}-\mathrm{BBN}$ plus ketoprofen 40 or $80 \mathrm{mg} / \mathrm{kg}$ diet. Sul: OH-BBN plus sulindac 200 or $400 \mathrm{mg} /$ $\mathrm{kg}$ diet.

(21). At a dose of $150 \mathrm{ppm}$ piroxicam, the incidence of colon tumor was reduced by as much as $84 \%$ compared to untreated controls. Sulindac was shown to have a protective effect against dimethylhydrazine-induced colonic tumors in the mouse. Sulindac administered with the carcinogen caused a significant reduction in tumor incidence and tumor burden, but sulindac administered $17 \mathrm{wk}$ after the carcinogen had no inhibitory effect, thus demonstrating protection against initiation of tumors but no effect on regression of established tumors in this model (22). Craven and DeRubertis (23) examined the influence of aspirin on dimethylhydrazine-induced colonic carcinogensis in rats. Incidence of adenocarcinomas was reduced $69 \%$ in rats receiving aspirin for $1 \mathrm{wk}$ before and after the carcinogen. Aspirin had no effect on tumor incidence when started 4 wk after carcinogen exposure. The aspirin dosage suppressed ex vivo colonic $\mathrm{PGE}_{2}$ production by $95 \%$. Treatment with aspirin for 1 wk inhibited both basal and arachidonate stimulated decomposition of the dimethylhydrazine metabolite methylazoxymethanol by colonic mucosal homogenates. The authors suggest that suppression of dimethylhydrazine-induced colonic carcinoma by aspirin may be altered by metabolic activation of the carcinogen by cyclooxygenase-dependent cooxidation.

\section{NSAIDs CAUSE REGRESSION OF POLYPS IN FAP}

A third line of evidence for the anticarcinogenic effect of NSAIDs is provided by studies of familial adenomatous polyposis (FAP), an autosomal dominant disorder characterized by the formation of hundreds of colorectal adenomas and development of colorectal cancer. Several studies have shown that the NSAID sulindac reverses co- 
lorectal polyp formation in FAP patients (24-27). Biopsy samples, direct observation of polyps, and measurements of levels of various enzymes and eicosanoids have been used in attempts to determine the mechanism of sulindac's effect on FAP. In general, results indicate that prostaglandin synthase is abnormally expressed in adenomatous polyps (28), eicosanoids (primarily PGEs and PGFs) are present at higher levels in tumor than nontumor tissue (29-31), and treatment with NSAIDs inhibits prostaglandin synthase and reduces tissue PG levels (32). However, the beneficial effects of sulindac in FAP may not be seen in sporadic colonic polyps (33).

An interesting mouse model of FAP has been developed by Jacoby et al. (34) and by Boolbol et al. (35) in which C57BL/6J-Min/ + mice, a strain containing a fully penetrant dominant mutation in the Apc tumor suppressor gene (leading to gastrointestinal adenomas by 110 days of age), are used to study FAP and NSAID treatment in experiments not possible with human patients. The mouse model allowed the investigators to precisely control environmental and genetic conditions in the development of neoplasia. In the sulindac study (35) three groups of mice were compared: normal C57BL/6J $(+/+)$ mice with the wild-type Apc gene, the dominant mutant C57BL/6J-Min/+ (Min) FAP mice, and the Min mice treated with sulindac (0.5 $\mathrm{mg} /$ day). At 110 days of age $+/+$ mice had no macroscopic intestinal tumors, Min mice had 11.9 tumors per mouse, and sulindac-treated Min mice had 0.1 tumors per mouse. Untreated Min mice had increased expression of PHS-2 protein, increased levels of prostaglandin $\left(\mathrm{PGE}_{2}\right)$ in the intestine, and a 27-47\% decrease in enterocyte apoptosis compared to $+/+$ animals. Sulindac treatment of Min animals inhibited tumor formation, decreased PHS-2 and $\mathrm{PGE}_{2}$ expression to normal levels, and restored normal levels of apoptosis, thus demonstrating the efficacy of sulindac in this mouse model. In a study using piroxicam in the Min mouse, Jacoby et al. (34) showed a dose-dependent decrease in intestinal adenomas and aberrant crypt foci as well as a parallel decrease in serum levels of thromboxane $B_{2}$.

\section{ARACHIDONATE METABOLISM}

Since the major known effect of the NSAIDs is inhibition of PG synthesis, the enzyme catalyzing the committed and rate-limiting step in production of PG has been investigated as the probable common target of NSAIDs. Prostaglandins are products of arachidonic acid, a 20-carbon unsaturated fatty acid found in membrane lipids. Arachidonic acid is metabolized, after release from membranes, by three major pathways: cyclooxygenase, lipoxygenase, and cytochrome $\mathrm{P} 450$ monooxygenase. An additional, nonenzymatic pathway of arachidonic conversion leads to isoprostanes that form by free radical peroxidation of the acid in situ in the phospholipid membrane. Formation of isoprostanes illustrates the formation of biologically active autacoids as a consequence of oxidative (free radical) tissue injury (36).

Each of the three major enzymatic pathways of arachidonate metabolism leads to a different series of compounds. The cyclooxygenase pathway results in prostaglandins of the $E_{2}, F_{2}$, and $D_{2}$ series. $P I_{2}$ (prostacyclin) and thromboxane $\mathrm{A}_{2}\left(\mathrm{TXA}_{2}\right)$ are also products of the cyclooxygenase metabolism of arachidonic acid. The common intermediate in the synthesis of prostaglandins in $\mathrm{PGG}_{2}$, a cyclic hydroperoxide formed by the addition of two molecules of $\mathrm{O}_{2}$ to arachidonic acid. $\mathrm{PGG}_{2}$ is then reduced to $\mathrm{PGH}_{2}$, an alcohol, which is further metabolized by isomerases and synthases to the tissue PGs.

PHS, the enzyme that forms $\mathrm{PGH}_{2}$ from arachidonic acid, has two distinct catalytic activities. It is a cyclooxygenase, as it cyclizes and oxygenates arachidonic acid to form $\mathrm{PGG}_{2}$, and it is a peroxidase that reduces $\mathrm{PGG}_{2}$ to $\mathrm{PGH}_{2}$, an alcohol. Because these two activities can be separately involved in other reactions and are inhibited by different substances, the name prostaglandin $\mathrm{H}$ synthase is probably preferable to the often-used COX (for cyclooxygenase) when referring to the enzyme. At least two isozymes of PHS are known: PHS-1 and PHS-2. Before about 1991, work with PHS did not distinguish between the enzyme isoforms; however, because most of this work used bovine or ovine seminal vesicles as the enzyme source, and this tissue has a high content of PHS-1, PHS-1 was most likely the form studied. PHS-2, in contrast to PHS1 , is almost undetectable in most unstimulated tissues. Exceptions appear to be the placenta and the brain of newborns $(37,38)$, where PHS-2 is readily detectable. PHS-2 is also present in parts of the kidney in the absence of inflammation. Renal PHS-2 levels increase in response to sodium restriction, which suggests that the enzyme is important in regulating salt, volume, and blood pressure homeostasis (39). The differences in distribution, inducibility, and regulation of expression of PHS-1 and -2 have been well covered in several recent reviews $(9,40-42)$.

Lipoxygenase (LOX) activity takes arachidonic acid along a different metabolic path by inserting one molecule of $\mathrm{O}_{2}$ to form hydroperoxyeicosatetraenoic acids (HPETEs). The actual product is 5-, 12-, or 15-HPETE, depending on which LOX is involved. HPETEs are next converted to their respective hydroxyeicosatetraenoic acids (HETEs). HETEs produced via the LOX pathway are of the $S$ configuration. Further metabolism results in leukotrienes and lipoxins, both of which exert diverse actions in inflammation and immunity (43).

The remaining enzymatic pathway of arachidonate metabolism involves enzymes of the cytochrome P450 family. These monooxygenases insert an atom of oxygen at various positions of arachidonic acid. P450 oxidation of arachidonic acid includes allylic oxidation, which is lipoxygenase-like in generating 5-, 8-, 9-, 11-, 12-, and 15-HETE. Omega hydroxylation reactions catalyzed by several $\mathrm{P} 450$ s oxidize C-19 and C-20 of arachidonic acid. Oxidation at C-16, -17 , and -18 has also been reported. Hydroxylation at the omega and omega-1 positions may produce HETEs 
with potent biological activities. The third major activity of P450s on arachidonic acid is epoxidation. This reaction produces epoxyeicosatrienoic acids (EETs) whose positional and stereochemical characteristics are controlled by the particular P450 catalyzing the epoxidation (44). The three pathways of arachidonate metabolism are summarized in Table 1.

\section{PROSTAGLANDIN H SYNTHASE AS THE TARGET OF NSAIDs}

Aspirin and all aspirin-like drugs including the NSAIDs are thought to exert their anti-inflammatory, antipyretic, and analgesic effects by inhibition of PHS $(45,46)$. Although the mechanism of inhibition varies for different agents, the overall effect, reduction of PG synthesis, is the same. Aspirin alters the channel leading to the PHS active site by irreversibly acetylating both PHS-1 (at serine 530) and PHS-2 (at the homologous serine 516), but the effect of this acetylation differs between isoforms. Aspirin-inhibited PHS-1 ceases formation of PG as its cyclooxygenase activity is lost. The irreversible nature of the inhibition means that PG synthesis can resume only when new PHS1 molecules are synthesized. In the case of platelets, even a small dose of aspirin inhibits PG and TBX production for a considerable period of time. Because platelets lack the machinery for synthesis of new enzyme, the aspirintreated platelets are prevented from synthesizing PG for their normal life span (8 to 11 days). The result of the acetylation of PHS-2 by aspirin is an increase in production of 15-HETE (47-49). Investigation of the source of 15-HETE demonstrated that it is indeed the product of PHS activity and is not produced by LOX or some other enzyme (47). Thus, a lipoxygenase activity has been added to the catalytic repertoire of PHS. Subsequent studies have determined that PHS-1 and -2 without aspirin treatment both produce small amounts of 15-HETE from arachidonate $(47,49)$ and that aspirin does not alter the production of 15-HETE by PHS-1. The 15-HETE produced by PHS is of the $R$ configuration, whereas that produced by 15 LOX is $S(49,50)$.

Indomethacin reacts with the active site of PHS and induces a conformational change in the protein. Ibuprofen inhibits PHS by substrate competition with arachidonic acid (51). The relative inhibitory concentrations of the NSAIDs for PHS-1 and PHS-2 have been investigated in various cell preparations (51) and in cells transfected with the recombinant mouse (48) or human enzymes (52). Although the actual values for inhibition constants varied depending on the experimental procedure and which parameter was being measured, the general pattern showed that almost all compounds tested were better inhibitors (lower $\mathrm{IC}_{50}$ values) of PHS-1 than of PHS-2. Flurbiprofen, ibuprofen, meclofenamate, and docosahexaenoic acid showed nearly equal inhibition of the isozymes. 6-Methoxy-2naphthyl acetic acid, the active metabolite of nabumetone, showed better inhibition of PHS-2 than PHS-1.
TABLE 1. Summary of arachidonate oxygenation

\begin{tabular}{llll}
\hline \hline Enzyme & \multicolumn{1}{c}{ Oxygen added } & Products & Further products \\
\hline $\begin{array}{l}\text { PHS- } \\
\text { cyclooxygenase }\end{array}$ & Two molecules $\mathrm{O}_{2}$ & $\mathrm{PGG}_{2}$ & $\mathrm{PGH}_{2}$ \\
$\begin{array}{l}\text { PHS-peroxidase } \\
\text { Lipoxygenases }\end{array}$ & $\begin{array}{l}\text { One molecule } \mathrm{O}_{2} \\
\text { P450s }\end{array}$ & $\begin{array}{l}\mathrm{HGE}_{2} \\
\text { One atom } 0\end{array}$ & $\begin{array}{l}\text { PGs, TX } \\
\text { HETE, Lipoxins, } \\
\text { Leukotrienes }\end{array}$ \\
\hline
\end{tabular}

${ }^{a}$ Abbreviations are defined in the text.

The interest in a specific inhibitor of PHS-2 arises from the proposition that the ulcerogenic and other adverse properties NSAIDs originate in the inhibition of PHS-1 whereas the therapeutically desirable effects come from inhibition of PHS-2 $(53,54)$. A flurry of activity among pharmaceutical companies has led to a number of potential drugs as inhibitors with at least relative specificity for PHS-2. One such compound, NS-398, was tested in vitro as an inhibitor of $\mathrm{PGE}_{2}$ production by purified ovine PHS1 and PHS-2. An $\mathrm{IC}_{50}$ value of $3.8 \times 10^{-6} \mathrm{M}$ was found with PHS-2 whereas PHS-1 activity was not inhibited even at $10^{-4} \mathrm{M}$ NS-398. By way of comparison, indomethacin was a virtually equipotent inhibitor of PHS-1 and PHS-2, with $\mathrm{IC}_{50}$ values of $7.4 \times 10^{-7} \mathrm{M}$ and $9.7 \times 10^{-7} \mathrm{M}$, respectively (55). The new compound (NS-398) also produced less gastrointestinal toxicity than standard NSAIDs. Masferrer et al. (56) used an air pouch model of inflammation in rats to show that NS-398, like dexamethasone, blocked PHS-2 expression in inflammatory cells lining the air pouch, resulting in complete surpression of PG synthesis. Neither dexamethasone nor NS-398 altered PG expression in the stomach. These results add support to the hypothesis that PHS-l is protective for tissues such as gastric mucosa and that PHS-2 is the isoform expressed during inflammation. Thus, it appears that specific inhibition of PHS-2 will be a major advance in anti-inflammatory therapy while significantly reducing adverse consequences of treatment.

Other specific PHS-2 inhibitors have been developed. CGP 28238 has been tested as an inhibitor of thromboxane synthesis by human platelets (PHS-1) and of prostacyclin synthesis by IL-6-stimulated rat mesangial cells (PHS-2). The ratios of $\mathrm{IC}_{50}$ values for PHS-1/PHS-2 were 0.15 for indomethacin, 15 for diclofenac, and 5000 for CGP 28238 (57). Another candidate PHS-2-specific inhibitor, L745,337 , was tested by measuring $\mathrm{PGE}_{2}$ production in cultured osteosarcoma cells (PHS-2) and U-937 cells (PHS-1). The ratio of $\mathrm{IC}_{50} \mathrm{PHS}-1 / \mathrm{CC}_{50} \mathrm{PHS}-2$ was about 500 . The compound inhibited rat paw edema and hyperalgesia, reduced the pyresis caused by endotoxin, and did not produce gastric lesions or alter gastrointestinal integrity. The compound did not lower $\mathrm{PGE}_{2}$ levels in the stomach (58). Results with CGP 28238 and L-745,337 further support the separate roles of PHS-1 and PHS-2 in gastric protection and inflammation, respectively. 
A study of the mechanism of specific PHS-2 inhibition by NS-398 and DuP697 (another PHS-2-specific anti-inflammatory) showed these compounds to be time-dependent competitive inhibitors. Both drugs inhibit PHS-l and PHS-2 with equal potency right after mixing, but the potency for PHS-2 increases with time whereas that for PHS1 remains low and constant. Further, PHS-1 can be reactivated by dialysis whereas PHS-2 shows no recovery of enzyme activity after dialysis (54). The authors suggest that the specific inhibition of PHS-2 involves an inhibitorinduced structural transition in PHS-2 that results in significant and irreversible loss of activity.

Although the results obtained with specific inhibitors of PHS-2 - namely, anti-inflammatory action without gastric ulceration-support the hypothesis that PHS-2 activity is proinflammatory and PHS-1 activity is cytoprotective, experiments with $P H S-I$ and $P H S-2$ knockout mice seem to contradict such a simple distinction of the roles of the isozymes. If PHS- 1 is responsible for synthesizing the PGs that protect against stomach ulceration, lack of PHS-1 should lead to ulcers. However, mice lacking the intact PHS-1 gene, and thus deficient in PHS-1 activity, do not develop spontaneous gastric ulcers and are actually less sensitive to gastric ulcers than normal mice after indomethacin treatment (59). The exclusive role of PHS-2 in inflammation is also challenged as $P H S-2$ knockout mice, shown to be devoid of PHS-2, exhibit no significant difference from normal mice in having an inflammatory response to tetradecanoyl phorbol acetate or arachidonic acid $(60,61)$. Although several possible explanations for the apparently contradictory results have been offered (62), more research is needed before the contribution of PHS isoforms to inflammation can be fully determined.

\section{INITIATION OF CARCINOGENESIS BY PROSTAGLANDIN H SYNTHASES}

PHS may be involved in the initiation of carcinogenesis by activation of carcinogens to DNA-binding forms. Although the cyclooxygenase activity of PHS is specific for arachidonic acid and only a few other polyunsaturated fatty acids, the peroxidase activity has a broad specificity. In addition to the primary substrate, PGG, other hydroperoxides can be reduced by PHS peroxidase. A large number of compounds can also be used as electron donors for "cooxidation." Among the classes of carcinogens that are used as electron donors, and thereby activated by PHS, are polycyclic aromatic hydrocarbons, aflatoxins, halogenated pesticides, aromatic amines, and phenols. (63).

Numerous examples of carcinogen-DNA adducts generated by PHS have been reported (reviewed in refs 64, 65). Activation of carcinogens by PHS occurs in numerous extrahepatic tissues and may be responsible for initiation of cancers in those tissues (66). Carcinogen activation by PHS can be distinguished from activation by P450 enzymes in vitro by the effect of specific cofactors on the reaction. Addition of arachidonic acid will promote PHS- catalyzed activation, whereas NADPH will increase activation by $\mathrm{P} 450$. Specific inhibitors are also useful in demonstrating PHS-catalyzed activation. Indomethacin or aspirin will inhibit carcinogen-DNA adduct formation via the PHS pathway $(66,67)$. High-peformance liquid cromatography (HPLC) analysis of carcinogen-DNA adducts formed either in vitro or in vivo can distinguish between PHS and P450 activation. Adducts formed via PHS activation are more polar and elute earlier in reversed phase HPLC than adducts produced by $\mathrm{P} 450$ activation $(67,68)$. Both purified PHS-1 (67) and PHS-2 (69) were able to activate 2-aminofluorene (AF) to a DNA binding metabolite. Transfection of COS-1 cells with human PHS-2 led to activation of $\mathrm{AF}$, which could be inhibited by indomethacin or aspirin. Addition of phorbol myristate acetate (PMA), a known inducer of PHS-2, to cultures of HUVEC cells caused a threefold increase in AF-DNA adduct formation and an increase in both PHS-2 mRNA and immunoreactive PHS-2 protein, with no effect on PHS-1 expression, supporting the role of PHS-2 in AF activation in these stimulated cells (69). Potentially carcinogenic compounds that pass through the colon in relatively high concentrations include bile acids and food-derived heterocyclic arylamines. Knowledge of the ability of these compounds to serve as substrates for PHS activation would be of interest in understanding the initiation of colon cancers.

Another way in which PHS may be involved in initiation of carcinogenesis is by the generation of malondialdehyde (MDA), a direct-acting mutagen in bacterial and mammalian test systems that is carcinogenic in rats and forms multiple adducts with deoxynucleotides. MDA is produced by nonenzymatic as well as enzymatic breakdown of PGH. Thromboxane synthase is particularly active in converting PGH to MDA. MDA is also formed during lipid peroxidation. Whereas MDA formation from PGH is inhibited by NSAIDs, MDA formed via lipid peroxidation is not (40).

A third mechanism for the involvement of PHS in tumor initiation involves peroxyl radicals as reactive intermediates (65). Peroxyl radicals are the most stable oxy radicals and are able to diffuse some distance from the site of their generation. Peroxyl radicals may be formed by PHS, during lipid peroxidation, or in the reaction of polyunsaturated fatty acid hydroperoxides with metals or metalloproteins. Peroxyl radicals can epoxidize double bonds of procarcinogens such as benzopyrene-7,8-diol or dihydroxy-dihydrobenzoanthracene to produce the ultimate carcinogens of these compounds. NSAIDs may reduce initiation via the peroxyl radical pathway by lessening the formation of these radicals by PHS.

A relatively straightforward explanation of NSAIDs as cancer preventive agents is possible. Since PHS isozymes are involved in activation of carcinogens, generation of carcinogenic malondialdehyde, and formation of carcinogenic peroxyl radicals, inhibition of PHS activity by NSAIDs lessens the initiation of cancers. However, this reasoning does not adequately explain the reduction in adenomas or existing malignant transformations that can 
occur with NSAID treatment. Effects of these drugs on other stages of neoplasia need to be examined. These effects may include inhibition of PG synthesis, inhibition of other reactions carried out by PHS, or effects independent of PHS.

\section{PROSTAGLANDIN H SYNTHASES AND PROSTAGLANDINS IN TUMORS AND TUMOR CELL LINES}

Clinical evidence of the regression of polyps in FAP patients treated with sulindac (70) and the epidemiologic demonstration of reduced risk of colon cancer by NSAID users (3) implicate arachidonic acid metabolites in colorectal cancer. The levels of prostaglandins in colon tumors has been compared to normal colon tissue. The cyclooxygenase metabolites $\mathrm{PGE}_{2}, \mathrm{PGF}_{2}, \mathrm{PGI}_{2}, \mathrm{TXA}_{2}$, and the 5lipoxygenase metabolite leukotriene $\mathrm{B}_{4}$ were measured in 21 pairs of surgically excised human colon tumors and normal colon mucosa (71). $\mathrm{PGE}_{2}$ was elevated about twofold $(P<0.01)$ in the cancer samples, whereas $\mathrm{PGI}_{2}$ was reduced about threefold $(P<0.05)$. No significant changes were found in the levels of $\mathrm{PGF}_{2}, \mathrm{TXA}_{2}$, or leukotriene. However, the authors also considered the ratio of $\mathrm{PGI}_{2}$ to $\mathrm{TXA}_{2}$, as these two prostanoids have opposing actions on platelet aggregation and vascular tone. In every paired sample, the ratio was reduced in the cancer sample between 3.4 and and 11.5-fold (71). This shift toward proaggregatory thromboxane may favor tumor invasiveness, whereas the relative decrease in prostacyclin may represent a decrease in antimetastatic activity (72).

Another investigation of PG levels in colon tumors measured $\mathrm{PGE}_{2}$ in mucosal biopsy specimens in normal-appearing mucosa from patients with adenomatous polyps and in normal-appearing mucosa from patients with colon cancer (73). Normal tissue from polyp patients averaged $165 \mathrm{pg} \mathrm{PGE} / 2 / \mathrm{mg}$ tissue; normal tissue from colon cancer patients was not significantly different, with $147 \mathrm{pg} \mathrm{PGE}_{2} /$ $\mathrm{mg}$ tissue. However, $\mathrm{PGE}_{2}$ was significantly increased in the adenomatous polyp to $227 \mathrm{pg} / \mathrm{mg}$, and was even further increased in the colon cancer to $440 \mathrm{pg} / \mathrm{mg}$. The increase in $\mathrm{PGE}_{2}$ level from normal to adenoma to cancer appears parallel to the role of the adenoma as a transitional step between normal and cancerous tissue.

Given that PGs are elevated in colonic tumors $(71,73)$ and that mRNA for both PHSs are found in intestinal tissue $(74,75)$, it is of interest to determine whether either or both isoforms of PHS are elevated in the cancerous colon. PHS-1 and -2 mRNAs were determined in human colorectal cancers, adenomas, and normal mucosa. PHS2 mRNA was increased in 12 of 14 carcinomas compared to the same patient's normal-appearing mucosa. In three of six pairs of adenomas and normal mucosa, the adenoma had increased PHS-2 mRNA transcripts. Six of 14 unpaired adenomas clearly showed $P H S-2$ mRNA. In contrast to $P H S-2, P H S-1$ mRNA levels were equivalent in normal mucosa and cancer (28).
Similar results were obtained in a study of PHS-1 and PHS-2 protein expression in human colon cancer. Immunoblot analysis was performed on protein from 25 matched colon cancers and nontumor tissue, four premalignant polyps, five control noncancerous colons, and three matched normal and cancerous breast tissue samples. PHS-1 was detected in all tissues. PHS-2 was not found in 23 of 25 normal colon tissues from cancer patients, but was found in 19 of the 25 paired samples of cancers from these patients. PHS-2 protein was not detected in the four premalignant polyps, the five control colon samples from noncancer patients, or any of the samples of normal or cancerous breast. In addition to the increased expression of PHS-2 protein in 19 of 25 colon cancers, PHS-1 protein was decreased in 21 of 25 colon cancers compared to normal colon (76). The evidence from the studies of Eberhart (28) and Kargman (76) support the contention of abnormal expression of PHS-2 as the source of the higher PGE $_{2}$ levels found in some human colon cancers.

Excised tumors and colonic biopsy specimens contain several cell types; thus, the cellular origin of prostanoids found in these samples is not certain. Premalignant or transformed colonocytes, stromal and vascular cells, tissue macrophages, and infiltrating lymphocytes are all among the cell types possibly responsible for prostanoid production in tumors. It is unlikely that infiltrating lymphocytes are the source of PG synthesis in tumors because the number of tumor infiltrating lymphocytes was shown to decrease in the more advanced tumors (77). Production of $\mathrm{PGE}_{2}$ by these tumors was confirmed by finding a greater than sevenfold increase in $\mathrm{PGE}_{2}$ in blood leaving the tumor compared to blood entering it. The ratio of PG in venous to arterial tumor blood flow showed a positive correlation with tumor severity and a negative correlation to the number of infiltrating lymphocytes.

Most of the basal colonic PG production in humans originates submucosally, in the muscularis (78). The same occurs in rat colon, where colon muscle layers were found to have 10-fold the PG synthetic capacity of the mucosa. The major PG synthesized in rat colon is $\mathrm{PGI}_{2}(79)$. As these results refer to basal PG synthesis in nontumor tissue, it is likely that PHS-l is the isozyme responsible. The occurrence of mRNA for PHS-1 in human (and rat) normal and tumor colon has been reported (75).

A more comprehensive survey of human tissues for $P H S-1$ and $P H S-2$ mRNAs was reported earlier by 0 'Neill and Ford-Hutchinson (74), who showed that most tissues express at least some $P H S-1$ and $P H S-2$ message even without stimulation. PHS-1 mRNA was relatively abundant in prostate, with lower levels in uterus, small intestine, mammary gland, stomach, and lung. Still lower levels were reported for thymus, liver, kidney, testis, and pancreas. The brain had the lowest amount of PHS-1 mRNA of the tissues tested. For PHS-2 mRNA, the pattern differed only in that the lung joined the prostate as the tissues in highest abundance. The tissue distribution study did not include the colon or rectum, and the use of whole tissue may obscure regional distribution within a tissue 
such as differential expression of mRNAs in different areas of the brain, kidney, or intestinal tract.

In situ hybridization experiments by Kutchera et al. (80) determined that PHS-2 was expressed in carcinomatous epthelial cells of the colon, but not in normal colonic epithelial cells. In contrast, PHS-1 was expressed in both normal and cancerous regions. Colon cancer cell lines in culture also overexpressed PHS-2. Noncancerous human epithelial cells in culture did not express PHS-2 until stimulated with interleukin-1, which caused them to reach PHS-2 levels equivalent to colon cancer cells.

Evidence in the preceding paragraphs indicates that abnormal production of PHS-2 occurs in many colon cancers. Thus, it is a logical step to examine the effect of PHS-2 specific inhibition as prevention or therapy for these cancers. The PHS-2-specific inhibitor SC-58635 was compared with the nonspecific inhibitor sulindac in the azoxymethane-induced colonic aberrant crypt foci assay in rats. Treatment with SC58635 at $1500 \mathrm{ppm}$ reduced the number of aberrant crypt foci per rat by $40 \%$, which was about the same reduction as seen with sulindac at 320 ppm. SC58635 at $150 \mathrm{ppm}$ was without effect. There were no ulcerogenic side effects of the SC58635 treatments (81). Whether this experiment indicates a role for specific inhibitors of PHS-2 in colon cancer prevention is still an open question.

\section{EFFECTS OF INHIBITION OF PROSTAGLANDIN H SYNTHASES ON CELLS}

Evidence that $\mathrm{PGs}$ are generally increased in colon tumors and that PHS-2 is overexpressed in these tumors strengthens the hypothesis that PGs synthesized by PHS-2 are involved in colorectal carcinogenesis. Since the normal regulatory control of PHS-2 expression is somehow lost in the tumors, and inhibitors of PHS (the NSAIDs) appear to cause regression of colonic tumors, research into the effects of PHS and its inhibition on colonic cell proliferation and death has been plentiful.

Colonocytes are programmed to proliferate, differentiate, and die in the normal progression from the base of colonic crypts to the surface of the lumen of normal colon. The number of colonocytes depends on the rate of proliferation and the rate of programmed cell death, apoptosis. An abnormality in one or more of the programs can result in neoplasia. Investigation of carcinogenic and anticarcinogenic mechanisms must consider both proliferation and apoptosis of cells. Two cultured lines of human colon adenocarcinomas, SW 1116 and HT-29, were treated with several eicosanoids and the proliferation rate, distribution in the cell cycle, and percentage of cells in apoptosis were measured (82). HT-29 cells showed increased proliferation in the presence of $\mathrm{PGE}_{2}$, its methyl ester, its dimethyl derivative, and leukotriene $B_{4}$. SW 1116 cells proliferated with the above-mentioned eicosanoids as well as with $\mathrm{PGI}_{2}$ and $\mathrm{PGF}_{2}$. The distribution of cells in the cycle was not affected by the eicosanoids tested. Likewise, the rate of apoptosis was not altered. The stable derivative of $\mathrm{PGE}_{2}$, dimethyl $\mathrm{PGE}_{2}$, was injected into normal mice and the rate of colonocyte proliferation was subsequently measured. A 3.6-fold stimulation of proliferation was found, but there was no change in the cell cycle distribution from that of control animals (82).

If exogenous $\mathrm{PGE}_{2}$ causes proliferation of colonic adenocarcinoma cells, what is the effect of lowering $\mathrm{PGE}_{2}$ by inhibiting PG synthesis? The NSAID sulindac is a prodrug that is metabolized to the active form, sulindac sulfide, by bacteria in the intestine of intact animals. Sulindac and its sulfide both reduced the rate of proliferation of cultured HT-29 cells, caused them to accummulate in the $G_{0} / G_{1}$ phase of the cell cycle, and increased the rate of apoptosis (83); sulindac sulfide was about sixfold as potent as sulindac. It was demonstrated by analysis of the culture medium that unmetabolized sulindac was indeed active in this system. In this study, neither PHS activity nor levels of PGs were determined. At the dosages used (0.1-1.2 mM for sulindac and 0.05-0.2 $\mathrm{mM}$ for sulindac sulfide), it is expected that PHS would be inhibited and PG synthesis blocked, but nothing in the experiment directly links prostaglandins to the action of sulindac or sulindac sulfide. The authors suggest that the antineoplastic effect of sulindac sulfide is due to the decrease in colonocyte proliferation and the increased rate of apoptosis.

Further work by Shiff et al. (84) demonstrated that other NSAIDs including aspirin, indomethacin, naproxen, and piroxicam, at or above concentrations achievable in plasma, all reduced proliferation and altered the morphology of HT-29 cells. Cell cycle distribution was altered by these drugs to increase the proportion in $G_{0} / G_{1}$ with a reduction in $\mathrm{S}$ phase cells. Aspirin and indomethacin also reduced the proportion in $\mathrm{G}_{2} / \mathrm{M}$, but naproxen and piroxicam did not. All the NSAIDs tested, except aspirin, induced apoptosis. This work shows that several NSAIDs have similar, but not identical, effects on tumor cells.

Of course, the fact that NSAIDs have a common target, namely PHSs, would suggest that any effect these drugs have in common is mediated via activity against this target. The work reviewed here showing a common property of NSAIDs to decrease tumor cell proliferation, alter morphology, cause cells to accumulate in $G_{0} / G_{1}$, and increase the rate of apoptosis tends to further substantiate the common target of the drugs. But is it possible that there is more than one common target for these compounds? Could NSAIDs inhibit colon cancer by a prostaglandin-independent pathway? There is significant evidence accumulating that certain NSAIDs may be general activators of apoptosis independent of their ability (or inability) to inhibit PHS.

In 1980, DeMello et al. (85) reported that anti-inflammatory drugs arrested growth of rat hepatoma and human fibroblast cultures in the $G_{1}$ phase. The effect was reversible in that washing out of the drugs was followed by resumption of cell growth. However, there was a lack of correlation between the ability of NSAIDs to inhibit cell growth and their potency as inhibitors of prostaglandin synthase. Meclofenamic acid and indomethacin inhibited 
TABLE 2. Inhibition of AOM-induced tumors and $P G E_{2}$ content (89)

\begin{tabular}{|c|c|c|c|}
\hline Carcinogen & $\begin{array}{l}\text { Treatment: } \\
\text { NSAID and dose }\end{array}$ & $\begin{array}{c}\text { Tumors, }{ }^{a} \% \\
\text { of } \\
\text { control }\end{array}$ & $\begin{array}{c}\mathrm{PGE}_{2} \text { content, } \\
\% \text { of control }\end{array}$ \\
\hline $\mathrm{AOM}$ & None & 100.0 & 100.0 \\
\hline AOM & Piroxicam $0.015 \%$ & $38.5^{c}$ & $17.3^{c}$ \\
\hline AOM & Sulindac $0.04 \%$ & $26.5^{c}$ & $40.3^{c}$ \\
\hline AOM & Sulindac sulfone $0.1 \%$ & $45.0^{\circ}$ & 105.4 \\
\hline AOM & Sulindac sulfone $0.2 \%$ & $21.5^{c}$ & 78.6 \\
\hline
\end{tabular}

cell growth only at concentrations far exceeding those required to inhibit PG synthesis. Phenacetin and salicylic acid, which do not inhibit PG synthesis, were cytostatic whereas antipyrine and aminopyrine, which are weak inhibitors, were not cytostatic.

A second line of evidence separating the effects of NSAIDs on cell growth from the effect on PG synthesis was that when indomethacin was used to inhibit cell growth, the inhibition could not be overcome by added PGs or arachidonic acid. If inhibition of PG synthesis were the mechanism of NSAID cytostasis, addition of PG would be expected to overcome the inhibition. This was not the case; in fact, higher concentrations of PG enhanced the cytostatic effect of indomethacin (85).

As mentioned previously, sulindac is a prodrug that is reversibly reduced (mainly by intestinal flora) to sulindac sulfide, which is several-fold more active as an anti-inflammatory than sulindac. However, sulindac can also be irreversibly oxidized to sulindac sulfone, which is devoid of prostaglandin inhibitory activity (86). Recently, Thompson et al. (87) demonstrated that although $100 \mu \mathrm{M}$ sulindac sulfide inhibited purified PHS-1 and PHS-2 85\% and $43 \%$, respectively, sulindac sulfone was not inhibitory for either enzyme at up to $1000 \mu \mathrm{M}$. To examine if sulindac sulfone was active in anticarcinogenesis, rats were dosed with 1-methyl-1-nitrosourea, a mammary carcinogen, and fed a standard diet, diet plus sulindac sulfone $(0.03 \%)$, diet plus sulindac sulfone $(0.06 \%)$, or diet plus sulindac $(0.06 \%)$. At 24 wk, the sulindac-fed rats had fewer mammary cancers than the controls; sulindac-sulfone treated rats $(0.03 \%$ dose $)$ also had fewer mammary cancers than the controls. The group on the higher dose of the sulfone $(0.06 \%)$ had the lowest incidence, lowest mean number of tumors per rat, and lowest tumor burden of the groups. This experiment demonstrated that sulindac sulfone, although devoid of antiprostaglandin synthase activity, is able to reduce mammary tumor occurence in this animal model, thus providing additional evidence for the divergence of PHS inhibition and tumor prevention.

Sulindac sulfone was also shown to inhibit growth of HT29 cells and other tumor and normal cells. Treatment with sulindac sulfone did not alter the distribution of cells in the cycle or cause differentiation of the cells. Cell number decreased dramatically in response to a major increase in the rate of apoptosis. Sulindac sulfide was two- to fourfold as effective as the sulfone in eliciting these responses (88).

The effect of the non-PHS inhibitor sulindac sulfone on azoxymethane-induced colon cancer in the rat was demonstrated by Alberts et al. (89). Two weeks after dosing with azoxymethane, rats were left untreated or treated with piroxicam $(0.015 \%)$, sulindac $(0.04 \%)$, or sulindac sulfone $(0.10$ or $0.20 \%)$ for 31 wk. Colonic neoplasms were reduced by all treatments, but colonic $\mathrm{PGE}_{2}$ content was reduced only by piroxicam and sulindac (Table 2). Whatever the mechanism of the antineoplastic effect of NSAIDs, it does not necessarily include antiprostaglandin activity.

Because a drug without anti-PG activity could suppress tumor growth in cells that contain PG, what would be the effect of NSAIDs on cells that do not synthesize PGs and lack PHS, the putative target for NSAIDs? An interesting experiment was carried out by Hanif et al. (90) with two human colon adenocarcinoma cell lines, HT-29 (which produces PGs) and HCT-15 (which does not produce PGs), to determine the role of PGs in the inhibition of proliferation and induction of apoptosis by NSAIDs. Culture medium from HCT-15 cells was devoid of PGs, whereas that from HT-29 contained $\mathrm{PGE}_{2}, \mathrm{PGF}_{2}$, and $\mathrm{PGI}_{2}$. If the media was supplemented with serum, HCT-15 cell media only had the PG levels found in the serum, but HT-29 cells had additional amounts of PGs above the serum levels. Stimulation of PG synthesis by A23187, arachidonic acid, and mellitin was unable to increase PG production by HCT-15, but gave three- to fivefold increases in PG production by HT-29 cells. Finally, RT-PCR failed to show any mRNA for PHS-1 or PHS-2 in HCT-15, whereas the messages were clearly seen in HT-29. Proliferation of HCT-15 cells was only modestly affected by addition of $\mathrm{PGE}_{2}$ or $\mathrm{PGF}_{2}$ (25\% increase), but was severely reduced by incubation with sulindac or piroxicam. Addition of PGs along with sulindac or piroxicam did not reverse the decrease in proliferation. Proliferation of HT-29 cells was slightly increased by exogenous PGs, severely reduced by sulindac and piroxicam, and severely reduced by addition of PGs with sulindac and piroxicam. Thus, in the cultured cell lines, the NSAIDs sulindac and piroxicam exerted their antiproliferative effect independent of PG synthesis (90).

An interesting third line of evidence that the antiproliferative effect of NSAIDs on colon cells is independent of PHS inhibition has recently been reported. The NSAIDs ketoprofen, ketorolac, and flurbiprofen are 2-aryl-propionic acid derivatives that are chiral compounds and can exist in the two enantiomeric forms $R$ and $S$. The stereospecific inhibition of PHS-2 by these three NSAIDs was assessed in guinea pig whole blood, LPS-stimulated human monocytes, and purified sheep placental enzyme (PHS-2). Parallel models for PHS-1, similarly tested, were clotting guinea pig blood, human polymorphonuclear cells, and enzyme purified from ram seminal vesicles (PHS-1). In all systems the $S$-enantiomers were far more inhibitory than the $R$-enantiomers. The differences in $\mathrm{IC}_{50}$ values of 
$S$ - vs. $R$-forms were as much as 500 -fold. In fact, the small inhibitory activity of the $R$-form could be accounted for by very minor contamination by the $S$-form $(<0.5 \%)(91)$.

The $S$ - and $R$-enantiomers of flurbiprofen were tested for an antiproliferative effect on normal rat colonocytes in vivo. After 30 days of flurbiprofen treatment, the animals were given bromodeoxy-uridine, killed, and the stomach and bowel were examined for ulceration and colonocyte whole crypt labeling. The mean area of ulceration in the small bowel of the rats given $S$-flurbiprofen was 20 -fold that of the rats given the $R$-form. The bromodeoxy-uridine labeling index of colonocytes, which indicates cells in Sphase, was $12.6 \%$ for control, $8.3 \%$ for $R$-flurbiprofen, and 9.7\% for $S$-flurbiprofen (92). These results indicate that even though PHS-1 and PHS-2 inhibition is stereoselective, with the $S$-enantiomer being the active form, the suppression of cell proliferation by the $R$-enenatiomer is not related to PHS-1 or PHS-2 isoenzymes and cell quiescence is an achiral process. The next step would be to test the effects of $R$ - and $S$-enantiomers in an experimental carcinogenesis model rather than in normal rat intestine. It would also be useful to try the enantiomers in a transformed cell line, such as HCT-15, that does not produce either PHS enzyme. The possibility that $R$-enantiomers of certain NSAIDs are anticarcinogenic, nonulcerogenic, and do not interfere with normal PG production could be an important advance in the treatment or prevention of colon cancer.

If NSAIDs exert their antiproliferative effects by nonPG-dependent mechanisms, what are some of the possibilities for the mechanisms of their actions? Abramson and Weissmann (93) have reviewed some of the possibilities. A number of biological processes other than PG synthesis are inhibited by NSAIDs, although some of the effects reported were observed at dosages several-fold above those obtainable in vivo and therefore may not be biologically relevant. Most NSAIDs are planar, anionic molecules that partition into lipid bilayers of plasma membranes; the more acidic the $\mathrm{pH}$ (as is found at inflammatory sites), the greater the lipophilicity; thus, it is expected that they would inhibit various membrane processes. Among the membrane-associated enzyme activities inhibited by NSAIDs are superoxide anion generation by NADPH oxidase, phopholipase $\mathrm{C}$ activity, and 12-HPETE peroxidase activity. Many NSAIDs interfere with uptake of arachidonic acid and its insertion into membranes and also interfere with anion transport across a variety of cell membranes. NSAIDs have also been shown to uncouple oxidative phosphorylation in mitochondria. The effects of NSAIDs listed above are independent of their ability to prevent synthesis of PGs; in fact, PGs and NSAIDs demonstrate similar effects on several of the processes mentioned.

Another common property of NSAIDs and related drugs that may explain their antineoplastic effect on colorectal cancer is their ability to induce apoptosis of colonocytes. The progressive genetic damage involving activation of oncogenes and loss of tumor suppressor genes as benign ad- enomas undergo transition to malignant adenocarcinomas has been well documented (94). It has also been recognized that the size of the continuously renewing cell population of the gastrointestinal tract depends on both cell proliferation and cell death via apoptosis. It has been found that at each of four histopathological stages of neoplastic transformation, there is a progressive inhibition of apoptosis. At $8 \mathrm{~h}$ of culture, the rate of apoptosis for normal colonocytes was $60 \%$ but for carcinoma-derived cells the rate was only $10 \%$. Similar differences were observed at $24 \mathrm{~h}$ (85\% and 30\%, respectively). Apoptotic rates for nonadenomatous polyps, FAP adenomas, and sporadic adenomas were between normal and carcinoma values (95). Histochemical staining for expression of $b c l-2$, which prolongs cell survival by inhibiting apoptosis, showed expression that was restricted to the proliferative zone at the base and lower third of the crypt-epithelial column in normal tissue. In the colorectal carcinomas, in contrast, bcl2 protein was observed throughout the malignant epithelium with no topographic restriction (89).

Additional recent reports have demonstrated that NSAIDs induce apoptosis in colon carcinoma cells. Piazza (88) reported that sulindac sulfide as well as sulindac sulfone, the metabolite lacking anti-PHS activity, induced apoptosis in HT-29 cells and several other normal and transformed cell lines from breast, melanoma, lung, and kidney. Sulindac sulfide was three- to fourfold as potent as the sulfone. Apoptosis rather than inhibition of cell proliferation, altered differentiation, or necrotic cell death was shown to be the mechanism for growth inhibition of cells by sulindac sulfide and sulfone.

Shiff and colleagues (83) also demonstrated the induction of apoptosis in HT-29 cells by sulindac and sulindac sulfide in a dose- and time-dependent manner that was reversible by washing out the drugs. The examination was subsequently extended to include aspirin, indomethacin, naproxen, and piroxicam (84). All four drugs reduced the proliferation and altered cell morphology of HT-29 cells in a dose- and time-dependent manner. The NSAIDs, except aspirin, induced apoptosis in this model.

Examination of the effect of sulindac on apoptosis in human FAP was conducted by Pasricha et al. (96). Twenty two patients with FAP were treated with sulindac for 9 months. At 3 and 6 months, there was a significant reduction in size and number of polyps in the treated group. No change was found in staining for proliferating cell nuclear antigen or distribution in the cell cycle. However, the mean apoptotic epithelial fraction was threefold higher after sulindac treatment: 31 vs. $10 \%(P=0.01)$. The effect of sulindac in increasing apoptosis seen with colon carcinoma cell lines also occurred with adenomatous polyps in vivo.

\section{EFFECT OF PROSTAGLANDIN H SYNTHASE OVEREXPRESSION ON INTESTINAL EPITHELIAL CELLS}

The effect of NSAIDs that inhibit PHS is induction of apoptosis and regression of carcinoma and adenomatous pol- 
yps. Overexpression of PHS would be expected to have the opposite effect and inhibit apoptosis and promote neoplasia. Tsujii and DuBois (97) tested this hypothesis by permanently transfecting rat intestinal epithelial cells (RIE-P) with a PHS-2 expression vector oriented in the sense direction (RIE-S) or, as a control, the anti-sense direction (RIE-AS). They found elevated PHS-2 protein expression and increased PG production, which was inhibited by sulindac sulfide in the RIE-S cells. Apoptosis was inhibited in the RIE-S cells, and sodium butyrate failed to induce apoptosis in these cells. Sulindac sulfide overcame this inhibition in a dose-dependent manner in the PHS-2 overexpressing cells.

Other changes in RIE-S cells included increased adhesion and a reduction in apoptosis after butyrate treatment. Sixfold more RIE-S cells attached to laminin- or Matrigel-coated plates than did RIE-AS or nontransfected RIE-P cells. All three lines attached equally to fibronectin-coated plates. Cells expressing PHS-2 were able to attach to Matrigel and survive on it, whereas cells without detectable PHS-2 were unable to do so. PHS-2 expression affected extracellular adhesion and survival. Apoptosis in RIE cells plated on extracellular matrix was measured with and without sodium butyrate treatment. Cells expressing PHS-2 were relatively resistant to apoptosis in both cases. Sulindac sulfide eliminated the resistance in a dosedependent manner. PHS-2 overexpression also inhibited cellular differentiation, as measured by alkaline phosphatase levels both with and without sodium butyrate treatment. Sulindac sulfide overcame the block in cellular differentiation and led to production of alkaline phosphatase in the PHS-2 expressing cells.

Overexpression of $\mathrm{PHS}-2$ was accompanied by increased levels of bcl-2, reduced TGF $\beta 2$ receptor protein levels, and absence of E-cadherin protein. All of these changes in RIE-S cells are in the direction of increased cell survival and increased tumorigenic potential. These results, taken together with the abnormal expression of PHS-2 in many human colon tumors, support the inhibition of PHS-2 by NSAIDs as the antineoplastic mechanism of this class of drugs (97). This hypothesis does not necessarily involve formation of PGs as the signal molecules inducing these tumorigenic effects.

If, as indicated, PHS-2 overexpression is associated with colon tumor formation and survival, what causes PHS-2 overexpression in vivo? The promoter region of PHS-2 contains numerous recognition elements that enable the gene to be activated by growth factors, cytokines, and tumor promoters $(98,99)$. PHS-2 expression may even be controlled by TCDD and other halogenated hydrocarbons $(100,101)$. Any of several malignant transformations in a cell causing abnormal expression of a growth factor could, in theory, lead to abnormal overexpression of PHS-2. The expression of PHS-2 in colon cancer compared to normal tissue was examined by Kutchera et al. (80), who compared PHS-2 expression in colon cancer and normal tissue from the same patients. All the tumor samples had increased PHS-2 expression. In situ hybridization confirmed that carcinomatous epithelial cells, but not the normal epithelial cells, expressed PHS-2. Low levels of PHS-1 were found in all cells.

Four colon cancer cell lines were examined for PHS-2 expression. All had constitutive expression of $P H S-2$. To test for increased transcription, a reporter gene was constructed consisting of a $2 \mathrm{~kb}$ fragment of the human PHS2 promoter ligated to luciferase. Transfection of the reporter construct into HCT-116 colon carcinoma cells showed extensive luciferase activity without a need for inducers. Transfection without the PHS-2 promoter did not show activity, and transfection with the promoter into noncancerous cells required additional induction to show activity. These experiments suggest that some factor overexpressed in carcinoma cells leads to up-regulation of the $P H S$-2 promoter (82). The up-regulation of PHS-2 may, in turn, produce the increased cell survival and tumorigenic potential reported by Tsujii and DuBois (97).

\section{EFFECTS OF NSAIDS ON TUMOR SUPPRESSOR AND CELL CYCLE REGULATORY PROTEINS}

$B c l-2$ is an oncogene that acts specifically by blocking apoptotic cell death. Expression of the bcl-2 protein has been reported in solid tumors as well as hemopoietic malignancies. Bcl-2 is differentially expressed in colonic crypts, suggesting a role for it in the regulation of colonic epithelium and possibly colorectal carcinogenesis. Hague et al. (102) examined human colorectal adenomas and carcinomas for bcl-2 expression and found aberrant expression in adenocarcinomas, adenomas, adenoma and carcinoma cell lines, and regional lymph node metastesis of colon carcinoma. The findings of abnormal expression of the $b l c-2$ gene is reminiscent of the abnormal expression of PHS-2 in many colorectal carcinomas described by Eberhart (28), Kargman (76), and Sano et al. (103) in humans and by Williams et al. (104) in Min mouse adenomas.

Work with the cultured cell line HT-29, which is derived from a moderately well-differentiated human colon adenocarcinoma, has identified several proteins that play a role in cell cycle progression and are affected by NSAIDs. Shiff et al. (84) found a marked reduction in levels of $\mathrm{p} 33^{\text {cdk2 }}$ and $\mathrm{p} 34^{\text {cdc2 }}$ after indomethacin or aspirin treatment of HT-29 cells. These cyclin-dependent kinases, together with cyclins, are essential for progression through the eukaryotic cell cycle (105). The decrease in p33 and p34 caused by NSAIDs parallels the accumulation of cells in $G_{0} / G_{1}$ and the decrease in cells in $S$ phase and $G_{2} / M$. Reduction in active cyclin-dependent kinases, leading to a halt in cell cycle progression, may be responsible for increased apoptosis and thus the antineoplastic action of NSAIDs.

Sulindac and sulindac sulfide prevent HT-29 cells from progressing from $G_{0} / G_{1}$ to $S$ phase. The cell cycle block is associated with an initial rise, then fall, in p34 ${ }^{\text {cdc2 }}$ protein 
(106). The regulatory units of the cdk's also decrease in response to sulindac: cyclins A and Bl were significantly reduced. These results suggest that sulindac and its sulfide induce a global decrease in the proteins of the cell cycle molecular engine. The content of other proteins was also changed by sulindac treatment. $\mathrm{p} 21^{\text {WAF/cipl }}$, which can arrest cell division by blocking the kinase activity of cdk's, was increased by sulindac. pRB, the retinoblastoma tumor suppressor protein, exists in HT-29 cells in phosphorylated and underphosphorylated forms. Both forms of $p R B$ were reduced by sulindac. HT-29 cells contain a mutated p53 tumor suppressor gene. Sulindac treatment reduces the levels of mutated p53. In summary, Goldberg et al. (106) found that the $G_{0} / G_{1}$ block induced by sulindac and sulindac sulfide in HT-29 cells is associated with an initial rise, followed by an abrupt decrease in $\mathrm{p} 34^{\text {cdk2 }}$, reduction of mitotic cyclins, an increase in $\mathrm{p} 21^{\mathrm{WAF} / \mathrm{ipl}}$, a reduction $\mathrm{pRB}$ with a relative increase in underphosphorylated $\mathrm{pRB}$, and a reduction in mutant p53. These responses are not associated with cell differentiation and not strictly associated with apoptosis. However, they may be the basis for the anticarcinogenic activity of NSAIDs.

\section{SUMMARY: MECHANISMS OF THE ANTINEOPLASTIC EFFECTS OF NSAIDs}

How NSAIDs prevent tumors and cause regression of colorectal adenomas and adenocarcinomas is not known. As is common in complex biological systems, there is probably more than one process affected by NSAIDs, and the mechanism of action of individual NSAIDs may differ slightly or significantly. In vitro it has been shown that several NSAIDs can prevent carcinogen-DNA adduct formation, an early step in tumor initiation. Studies of experimental carcinogenesis in animals have also shown that NSAIDs can prevent chemical carcinogenesis and also reverse tumor formation when the drugs are administered simultaneously with, or even weeks after, carcinogen exposure. Clinical studies have demonstrated reduction in polyps and adenomas in patients with familial adenomatous polyposis as well as decreased progression to adenocarcinomas in these patients. Epidemiologic studies have clearly demonstrated greatly lowered incidence and also mortality from colorectal cancers in users of NSAIDs. No single mechanism has yet been shown to account for all of these findings.

Evidence exists for the activity of PHS isozymes in the activation of carcinogens to DNA damaging metabolites. NSAIDs inhibit this activation. Several NSAIDs induce apoptosis in colon epithelial cells, which seems to overcome the inhibition of apoptosis that occurs in colorectal cancer. A return to the normal rate of cell death would certainly support tumor regression. The induction of apoptosis appears to be independent of prostaglandin synthase activity, as this effect of NSAIDs has been demonstrated in cells devoid of PHS isozymes (93). NSAIDs mediate several changes in cell cycle regulation.
Some of these effects on tumor suppressor genes, cyclins, and cyclin kinases have been mentioned. There are undoubtedly many other factors in normal and malignant cell regulation that are influenced by NSAIDs. Again, differences in the actions of the various NSAIDs are possible. For example, aspirin and salicylate, but not indomethacin, were found to inhibit activation of the transcription factor NF-B, which is critical for the expression of multiple cellular genes involved in inflammation, immunity, and adhesion (107). Of particular interest to arachidonic acid metabolism, the human arachidonate 12-lipoxygenase gene has a negative regulatory region containing the NFB motif (108). Thus, it is conceivable that salicyclates may inhibit NF-B, resulting in inhibition of various cellular enzymes and factors and the loss of negative control of 12 lipoxygenase. This would probably divert greater than normal amounts of arachidonic acid into the lipoxygenase pathway at the expense of the prostaglandin $\mathrm{H}$ synthase pathway. PHS-2 also has an NF-B regulatory motif that may serve to increase transcription of the gene (98). Inhibition of activation by salicyclates may result in lower than normal levels of PHS-2.

NSAIDs as a class have targets other than prostaglandin $\mathrm{H}$ synthases. Inhibition of NADPH oxidase, phospholipase $\mathrm{C}$, and 12-HPETE peroxidase as well as disruption of arachidonic acid uptake and insertion into membranes, interference with transmembrane anion transport, and uncoupling of mitochondrial oxidative phosphorylation have all been mentioned as common effects of NSAIDs (93), although the biological importance of these effects is unclear. It would be of great interest to test whether NSAID-like drugs that are inactive in PHS inhibition but have antineoplastic activity (sulindac sulfone) share the above properties. Similarly, PHS-2 specific inhibitors need to be tested for both antineoplastic activity and inhibition of membrane-associated enzyme activities.

There are still some prostaglandin $\mathrm{H}$ synthase-dependent mechanisms that need additional consideration as factors in the antineoplastic action of NSAIDs. When PHS-2 is acetylated by aspirin, PG production decreases markedly, but a new product, 15(R)-HETE, is produced $(47-49)$. The biological activity of this compound is largely unknown. Additional compounds of the class of $15 R$-epimers of lipoxins are produced when HUVEC and neutrophils are coincubated with aspirin but not indomethacin, salicylate, or dexamethasone. It is thought these compounds, which are bioactive in the nanomolar range, are produced by the interaction of acetylated PHS-2 and 5 -lipoxygenase (109). There may be other compounds produced by NSAID treatment of arachidonate metabolizing enzymes that remain undiscovered and could have important effects on cell growth and death.

Clinical and experimental evidence that NSAIDs are anticarcinogenic is strong, and recent studies have suggested PHS-independent mechanisms for this action. The exact relationship of PHS inhibition by NSAIDs to tumor prevention remains uncertain. Whether or not PHS, as the common target of NSAIDs, is involved in the protective 
effect of these drugs, the drugs and newer members of this class, particularly PHS-2-specific inhibitors (81) and specific enantiomers of chiral NSAIDs $(91,92)$, should be examined further as preventive and possibly curative agents for colon and rectal cancers.

The author wishes to thank Dr. Wendell Weber for suggestions and a helpful reading of the manuscript. The author has been supported by grant CA39018 from the National Institutes of Health.

\section{REFERENCES}

1. Kune, G. A., Kune, S., and Watson, L. F. (1988) Colorectal cancer risk, chronic illnesses, operations, and medications: case control results from the Melbourne Colorectal Cancer Study. Cancer Res. 48, 4399-4304

2. Rosenberg, L., Palmer, J. R., Zauber, A. G., Warshauer, M. E., Stolley, P. D., and Shapiro, S. (1991) A hypothesis: nonsteroidal anti-inflammatory drugs reduce the incidence of large-bowel cancer. J. Natl. Cancer Inst. 83, 355-358

3. Thun, M. J., Namboodiri, M. M., and Heath, C. W. (1991) Aspirin use and reduced risk of fatal colon cancer. New Engl. J. Med. 325, 15931596

4. Peleg, I. I., Maiboch, H. T., Brown, S. H., and Wilcox, C. M. (1994) Aspirin and non-steroidal anti-inflammatory drug use and the risk of subsequent colorectal cancer. Arch. Int. Med. 154, 394-399

5. Suh, O., Mettlin, C., and Petrelli, N. J. (1993) Aspirin use, cancer, and polyps of the large bowel. Cancer 72, 1171-1177

6. Gridley, G., McLoughlin, J. K., Ekbom, A., Klareskog, L., Adami, H. O., Hacker, D. G. Hoover, R., and Fraumeni, J. R., Jr. (1993) Incidence of cancer among patients with rheumatoid arthritis. J. Natl. Cancer Inst. 85, 307-311

7. Schreinemacher, D. M., and Everson, R. B. (1994) Aspirin use and lung, colon, and breast cancer incidence in a prospective study. Epidemiology $5,138-146$

8. Paganini-Hill, A., Chao, A., Ross, R. K., and Henderson, B. E. (1989) Aspirin use and chronic disease: a cohort study of the elderly. Br. Med. J. 229, 1247-1250

9. Herschman, H. R. (1994) Regulation of prostaglandin synthase-1 and prostaglandin synthase-2. Cancer Metastasis Rev. 13, 241-256

10. Peleg, I. I., Lubin, M. F., Cotsonis, G. A., Clark, W. S., and Wilcox, C. M. (1996) Long-term use of nonsteroidal antiinflammatory drugs and other chemopreventors and risk of subsequent colorectal neoplasia. $\mathrm{Di}$ gest. Dis. Sci. 41, 1319-1326.

11. Thun, M. J., Namboodiri, M. M., Calle, E. E., Flanders, W. D., and Heath, C. W. (1993) Aspirin use and the risk of fatal cancer. Cancer Res. 53, 1322-1327

12. Rubio, C. A. (1984) Antitumoral activity of indomethacin on esophageal tumors. J. Natl. Cancer Inst. 72, 705-707

13. Takahashi, M., Furukawa, F., Toyoda, K., Sato, H., Hasegawa, R., Imaida, K., and Hayashi, Y. (1990) Effects of various prostaglandin synthesis inhibitors on pancreatic carcinogenesis in hamsters after initiation with N-nitrosobis-(2-oxopropyl)amine. Carcinogenesis 11, 393-395

14. Murasaki, G., Zenser, T. V., Davis, B. B., and Cohen, S. M. (1984) Inhibition by aspirin of N-(4-(5-nitro-2-furyl)-2-thiazolyl)-formamide-induced bladder carcinogenesis and enhancement of forestomach carcinogenesis. Carcinogenesis 5, 53-55

15. Carter, C. A., Ip, M. M., and Ip, C. (1989) A comparison of the effects of the prostaglaandin synthesis inhibitors indomethacin and carprofen on 7,12 dimethylbenz(a)anthracene-induced mamamry tumorigenesis in rats fed different amounts of essential fatty acid. Carcinogenesis 10 1369-1374

16. Rao, K. V. N., Detrisac, C. J., Steele, V. E., Hawk, E. T., Kellof, G. J., and McCormick, D. L. (1996) Differential activity of aspirin, ketoprofen and sulindac as cancer chemopreventive agents in the mouse urinary bladder. Carcinogenesis 17, 1435-1438

17. Klan, R., Knispel, H. H., and Meier, T. (1993) Acetylsalicylic acid inhibition of N-butyl-(4-hydroxybutyl)nitrosamine-induced bladder carcinogenesis in rats. J. Cancer Res. Clin. Oncol. 119, 482-485

18. Pollard, M., and Luckert, P. H. (1980) Indomethacin treatment of rats with dimethylhydrazine-induced intestinal tumors. Cancer Treat. Rep. 64, 1323-1327

19. Narisawa, T., Sato, M., Tani, M., Kudo. T., Takahashi, T., and Goto, A. (1981) Inhibition of development of methylnitrosourea-induced rat colon tumors by indomethacin treatment. Cancer Res. 41, 1954-1957

20. Metzger, U., Meier, J., Uhlschmid, G., and Weihe, H. (1984) Influence of various prostaglandin synthesis inhibitors on DMH-induced rat colon cancer. Dis. Colon Rectum 27, 366-369
21. Reddy, B. S., Marayama, H., and Kellof, G. (1987) Dose-related inhibition of colon carcinogenesis by prioxicam, a non-steroidal anti-inflammatory drug, during different stages of rat colon tumor development. Cancer Res. 47, 5340-5346

22. Moorghen, M., Ince, P., Finney, K., Sunter, J. P., Appleton, D. R., and Watson, A. J. (1988) A protective effect of sulindac against chemicallyinduced primary colonic tumors in mice. J. Pathol. 156, 341-347

23. Craven, P. A., and DeRubertis, F. R. (1992) Effects of aspirin on 1,2dimethylhydrazine-induced colonic carcinogenesis. Carcinogenesis 13, 541-546

24. Waddell, W. R., and Loughry, R. W. (1983) Sulindac for polyposis of the colon. J. Surg. Oncol. 24, 83-87

25. Rigau, J., Pique, J. M., Rubio, E., Planas, R., Tarrech, J. M., and Bordas, J. M. (1991) Effects of long-term sulindac therapy on colonic polyposis. Ann. Int. Med. 115, 952-954

26. Giardiello, F. M., Hamilton, S. R., Krush, A. J., Piantadosi, S., Hylind, L. M., Celano, P., Booker, S. V., Robinson, C. R., and Offerhaus, G. J. (1993) Treatment of colonic and rectal adenomas with sulindac in familial adenomatous polyposis. $N$. Engl. J. Med. 328, 1313-1316

27. Nugent, K. P., Farmer, K. C., Spigelman, A. D., Williams, C. B., and Phillips, R. K. (1993) Randomized control trial of the effect of sulindac on duodenal and rectal polyposis and cell proliferation in patients with familial adenomatous polyposis. Br. J. Surg. 80, 1618-1619

28. Eberhart, C. E., Coffey, R. J., Radhika, A., Giardiello, F. M., Ferrenbach, S., and Dubois, R. N. (1994) Up-regulation of cyclooxygenase 2 gene expression in human colorectal adenomas and adenocarcinomas. Gastroenterology 107, 1183-1188

29. Bennett, A., Del Tacca, M., Stamford, I. F., and Zebro, T. (1977) Prostaglandins from tumors of the large bowel. Br. J. Surg. 35, 882-884

30. Hubbard, W. C., Alley, M. C., McLemore, T. L., and Boyd, M. R. (1988) Profiles of prostaglandin biosynthesis in sixteen established cell lines derived from human lung, colon, prostate, and ovarian tumors. Cancer Res. 48, 4770-4775

31. Narisawa, T., Kusaka, H., Yamazaki, Y., Takahashi, M., Koyama, H., Koyama, K., Fukaura, Y., and Wakizaka, A. (1990) Relationship between blood plasma prostaglandin $\mathrm{E}_{2}$ and liver and lung metastases in colorectal cancer. Dis. Colon Rectum 33, 840-845

32. Nugent, K. P., Spigelman, A. D., and Philips, R. K. S. (1996) Tissue prostaglandin levels in familial adenomatous polyposis patients treated with sulindac. Dis. Colon Rectum 39, 659-662

33. Ladenheim, J., Garcia, G., Titzer, D., Herzenberg, H., Lavori, P., Edson, R., and Omary, M. B. (1995) Effects of sulindac on sporadic colonic polyps. Gastroenterology 108, 1083-1087

34. Jacoby, R. F., Marshall, D. J., Newton, M. A., Novakovic, K., Tutsch, K., Cole, C. E., Lubet, R. A., Kelloff, G. J., Verma, A., Moser, A. R., and Dove, W. F. (1996) Chemoprevention of spontaneous intestinal adeomas in the Apc Min mouse model by the nonsteroidal anti-inflammatory drug piroxicam. Cancer Res. 56, 710-714

35. Boolbol, S. K., Dannenberg, A. J., Chadburg, A., Martucci, C., Guo, X.-J., Ramonetti, J. T., Abreu-Goris, M., Newmark, H. L., Lipkin, M. L., DeCosse, J. J., and Bertagnolli, M. M. (1996) Cyclooxygenase-2 overexpression and tumor formation are blocked by sulindac in a murine model of familial adenomatous polyposis. Cancer Res. 56, 2556-2560

36. Morrow, J. D., Hill, K. E., Nammoac, T. M., Badr, K. F., and Roberts L. J. (1990) A series of prostaglandin $F_{2}$-like compounds are produced in vivo in humans by a non-cyclooxygenase, free radical-catalyzed mechanism. Proc. Natl. Acad. Sci. USA 87, 9383-9387

37. Hirst, J. J., Teixeira, F. J., Zakar, T., and Olson, D. M. (1995) Prostaglandin endoperoxide- $\mathrm{H}$ synthase-1 and -2 messenger ribonucleic acid levels in human amnion with spontaneous labor onset. J. Clin. Endocrinol. Metab. 80, 517-523

38. Peri, K. G., Hardy, P., Li, D. Y., Varma, D. R., and Chemtob, S. (1995) Prostaglandin G/H synthase-2 is a major contributor of brain prostaglandins in the newborn. J. Biol. Chem. 270, 24615-24620

39. Harris, R. C., McKanna, J. A., Akai, Y., Jacobson, H. R., Dubois, R. N., and Breyer, M. D. (1994) Cyclooxygenase-2 is associated with the macula densa of rat kidney and increases with salt restriction. J. Clin. Invest. 94, 2504-2510

40. Marnett, L. J. (1992) Aspirin and the potential role of prostaglandins in colon cancer. Cancer Res. 52, 5575-5589

41. Goppelt-Struebe, M. (1995) Regulation of prostaglandin endoperoxide synthase (cyclooxygenase) isozyme expression. Prostaglandins Leukotrienes Essent. Fatty Acids 52, 213-222

42. Smith, W. L., and DeWitt, D. L. (1995): Biochemistry of prostaglandin endoperoxide $\mathrm{H}$ synthase-1 and synthase-2 and their differential susceptibility to nonsteroidal anti-inflammatory drugs. Semin. Nephrol. 15, 179-194

43. Samuelsson, B., Dahlén, S.-E., Lindgren, J. 'A., Rouzer, C. A., and Serhan, C. N. (1987) Leukotrienes and lipoxins: structures, biosynthesis, and biological effects. Science 237, 1171-1176

44. Capdevila, J. H., Falck, J. R., and Estabrook, R. W. (1992) Cytochrome P450 and the arachidonate cascade. FASEB J. 6, 731-736

45. Vane, J. R. (1971) Inhibition of prostaglandin synthesis as a mechanism of action of the aspirin-like drugs. Nature New Biol. 231, 232-235

46. Vane, J. (1994) Towards a better aspirin. Nature (London) 367, 215216 
47. Holtzman, M. J., Turk, J., and Shornick, L. P. (1992) Identification of a pharmcologically distinct prostaglandin $\mathrm{H}$ synthase in cultured epithelial cells. J. Biol. Chem. 267, 21438-21445

48. Meade, E. A., Smith, W. L., and DeWitt, D. L. (1993) Differential inhibition of prostaglandin endoperoxide synthase (cyclooxygenase) isoenzymes by aspirin and other non-steroidal anti-inflammatory drugs. J. Biol. Chem. 268, 6610-6614

49. O’Neill G. P., Mancini J. A., Kargman S., Yergey, J., Kwan, M. Y., Falgueyret, J. P., Abramovitz, M., Kennedy, B. P., Ouellet, M., Cromlish, W., et al. (1994) Overexpression of human prostaglandin G/H synthetase1 and -2 by recombinant vaccinia virus: inhibition by nonstreoidal antiinflammatory drugs and biosynthesis of 15-hydroxyeicosatetranoic acid. Mol. Pharmacol. 45, 245-254

50. Lecomte, M., Laneuville, O. Chuan, J., DeWitt, D. L., and Smith, W. L. (1994) Acetylation of human prostaglandin endoperoxide synthase-2 (cyclooxygenase-2) by aspirin. J. Biol. Chem. 269, 13207-13215

51. Mitchell, J. A., Akarasereenont, P., Thiemermann, C., Flower, R. J., and Vane, J. R. (1994) Selectivity of nonsteroidal antiinflammatory drugs as inhibitors of constitutive and inducible cyclooxygenase. Proc. Natl. Acad. Sci. USA 90, 11693-11697

52. Laneuville, O., Breuer, D. K., DeWitt, D. L., Hla, T., Funk, C. D., and Smith, W. D. (1994) Differential inhibition of human prostaglandin endoperoxide $\mathrm{H}$ synthases-1 and -2 by nonsteroidal anti-inflammatory drugs. J. Pharmacol. Exp. Ther. 271, 927-932

53. Vane, J. R., and Botting, R. M. (1995) A better understanding of antiinflammatory drugs based on isoforms of cyclooxygenase (COX-1 and COX-2). Adv. Prostaglandin Thromboxane Leukotriene Res. 23, 41-48

54. Copeland, R. A., Williams, J. M., Giannaras, J., Nurnberg, S., Covington, M., Pinto, D., Pick, S., and Trzaskos, J. M. (1994) Mechanism of selective inhibition of the inducible isoform of prostaglandin $\mathrm{G} / \mathrm{H}$ synthase. Proc. Natl. Acad. Sci. USA 91, 11202-11206

55. Futaki N., Takahashi S., Yokoyama M., Arai I., Higuchi S., and Otomo S. (1994) NS-398, a new anti-inflammatory agent, selectively inhibits prostaglandin $\mathrm{G} / \mathrm{H}$ synthase/cyclooxygenase (COX-2) activity in vitro. Prostaglandins 47, 55-59

56. Masferrer J. L., Zweifel B. S., Manning P. T., Hauser, S. D., Leahy, K. M., Smith, W. G., Isakson, P. C., and Seibert, K. (1994) Selective inhibition of inducible cyclooxygenase 2 in vivo is antiinflammatory and nonulcerogenic. Proc. Natl. Acad. Sci. USA 91, 3228-3232

57. Klein, T., Nusing, R. M., Pfeilschifter, J., and Ullrich, V. (1994) Selective inhibition of cyclooxygenase 2. Biochem. Pharmacol. 48, 1605-1610

58. Chan, C.-C., Boyce, S., Brideau, C., Ford-Hutchinson, A. W., Gordon, R., Guay, D., Hill, R. G., Li, C.-S., Mancini, J., Penneton, M., Prasit, P., Rasori, R., Riendeau, D., Roy, P., Tagari, P., Vickers, P., Wong, E., and Rodger, I. W. (1995) Pharmacology of a selective cyclooxygenase-2 inhibitor, L-745,337: A novel nonsteroidal anti-inflammatory agent with an ulcerogenic sparing effect in rat and nonhuman primate stomach. $J$. Pharm. Exp. Ther. 274, 1531-1537

59. Langenbach, R., Morham, S. G., Tiano, H. F., Loftin, C. D., Ghanayem, B. I., Chulada, P. C., Mahler, J. F., Lee, C. A., Goulding, E. H., Kluckman, K. D., Kim, H. S., and Smithies, O. (1995) Prostaglandin synthase 1 gene disruption in mice reduces arachidonic acid-induced inflammation and indomethacin-induced gastric ulceration. Cell 83, 483-492

60. Dinchuk, J. E., Car, B. D., Focht, R. J., Johnston, J. J., Jaffee, B. D., Covington, M. B., Contel, N. R., Eng, V. M., Collins, R. J., Czerniak, P. M., Gorry, S. A., and Trzaskos, J. M. (1995) Renal abnormalities and an altered inflammatory response in mice lacking cyclooxygenase II. $\mathrm{Na}$ ture (London) 378, 406-409

61. Morham, S. G., Langenbach, R., Loftin, C. D., Tiano, H. F., Vouloumanos, N., Jennette, J. C., Mahler, J. F., Kluckman, K. D., Ledford, A., Lee, C. A., and Smithies, O. (1995) Prostaglandin synthase 2 gene disruption causes severe renal pathology in the mouse. Cell 83, 473-482

62. DeWitt, D., and Smith, W. L. (1995) Yes, but do they still get headaches? Cell 83, 345-348

63. Reed, G. A. (1988) Oxidation of environmental carcinogens by prostaglandin $\mathrm{H}$ synthase. J. Environ. Sci. Health Part C: Environ. Carcinogen. Rev. C6, 223-259

64. Eling, T. E., Thompson, D. C., Foureman, G. L., Curtis, J. F., and Hughes, M. F. (1990) Prostaglandin H synthase and xenobiotic oxidation. Annu. Rev. Pharmacol. Toxicol. 30, 1-45

65. Marnett, L. J. (1990) Prostaglandin synthase-mediated metabolism of carcinogens and a potential role for peroxyl radicals as positive intermediates. Environ. Health Perspect. 88, 5-12

66. Flammang, T. J., Yamazoe, Y., Benson, R. W., Roberts, D. W., Potter, D. W., Chu, D. Z., Lang N. P., and Kadlubar, F. F. (1989) Arachidonic acid-dependent peroxidative activation of carcinogenic arylamines by extrahepatic human tissue microsomes. Cancer Res. 49, 1977-1982

67. Levy, G. N., and Weber, W. W. (1992) 2-Aminofluorene-DNA adducts in mouse urinary bladder: effect of age, sex, and acetylator status. Carcinogenesis 13, 159-164

68. Krauss R. S., and Eling, T. E. (1985) Formation of unique arylamine:DNA adducts from 2-aminofluorene activated by prostaglandin $\mathrm{H}$ synthase. Cancer Res. 45, 1680-1686

69. Liu, Y., Levy, G. N., and Weber, W. W. (1995) Activation of 2-aminofluorene by prostaglandin endoperoxide $\mathrm{H}$ synthase-2. Biochem. Biophys. Res. Commun. 215, 346-354
70. Waddell, W. R., Ganser, G. F., Cerise, E. J., and Loghry, R. W. (1989) Sulindac for polyposis of the colon. Am. J. Surg. 157, 175-179

71. Rigas, B., Goldman, I. S., and Levine, L. (1993) Altered eicosanoid levels in human colon cancer. J. Lab. Clin. Med. 122, 518-523

72. Honn, K. V., Busse, W. D., and Sloane, B. F. (1983) Prostacyclin and thromboxanes: implications for their role in tumor cell metastasis. Biochem. Pharmacol. 32, 1-11

73. Earnest, D. L., Hixson, L. J., and Alberts, D. S. (1992) Piroxicam and other cyclooxygenase inhibitors: Potential for cancer prevention. J. Cell. Biochem. 161, 156-166

74. O'Neill, G. P., and Ford-Hutchinson, A. W. (1993) Expression of mRNA for cyclooxygenase-1 and cyclooxygenase- 2 in human tissues. FEBS Lett. $330,156-160$

75. Gustafson-Svärd, C., Lilja, I., Hallböök, O., and Sjödahl, R. (1996) Cyclooxygenase-1 and cyclooxygenase-2 gene expression in human colorectal adenocarcinomas and in azoxymethane induced colonic tumours in rats. Gut 38, 79-84

76. Kargman, S. L., O'Neill, G. P., Vickers, P. J., Evans, J. F., Mancini, J. A., and Jothy, S. (1995) Expression of prostaglandin G/H synthase-1 and -2 protein in human colon cancer. Cancer Res. 55, 2556-2559

77. Kubota, Y., Sunouchi, K., Ono, M., Sawada, T., and Muto, T. (1992) Local immunity and metastasis of colorectal carcinoma. Dis. Colon Rectum 35, $645-650$

78. Mikkelsen, H. B., Rumessen, J. J., and Qvortrup, K (1991) Prostaglandin H synthase immunoreactivity in human gut. Histochemistry 96, 295-299

79. Lee, D. Y., Lupton, J. R., and Chapkin, R. S. (1992) Prostaglandin profile and synthetic capacity of the colon: Comparison of tissue sources and subcellular fractions. Prostaglandins 43, 143-164

80. Kutchera, W., Jones, D. A., Matsunami, N., Groden, J., McIntyre, T. M., Zimmerman, G. A., White, R. L., and Prescott, S. M. (1996) Prostaglanidn $\mathrm{H}$ synthase $\mathbf{2}$ is expressed abnormally in human colon cancer: evidence for a transcriptional effect. Proc. Natl. Acad. Sci. USA 93, 4816-4820

81. Reddy, B. S., Chinthalapally, V. R., and Seibert, K. (1996) Evaluation of cyclooxygenase-2 inhibitor for potential chemopreventive properties in colon carcinogenesis. Cancer Res. 56, 4566-4569

82. Qiao, L., Kozoni, V., Tsioulias, G. J., Koutsos, M. I., Hanif, R., Shiff, S. J., and Rigas, B. (1995) Selected eicosanoids increase the proliferation rate of human colon carcinoma cell lines and mouse colonocytes in vivo. Biochim. Biophys. Acta 1258, 215-223

83. Shiff, S. J., Qiao, L., Tsai, L.-L., and Rigas, B. (1995) Sulindac sulfide, an aspirin-like compound, inhibits proliferation, causes cell cycle quiescence, and induces apoptosis in HT-29 colon adenocarcinoma cells. J. Clin. Invest. 96, 491-503

84. Shiff, S. J., Koustsos, M. I., Qiao, L., and Rigas, B. (1996) Nonsteroidal antiinflammatory drugs inhibit the proliferation of colon adenocarcinoma cells: effects on cell cycle and apoptosis. Exp. Cell Res. 222, 179-188

85. DeMello, M. C. F., Bayer, B. M., and Beaven, M. A. (1980) Evidence that prostaglandins do not have a role in the cytostatic action of antiinflammatory drugs. Biochem. Pharmacol. 29, 311-318

86. Duggan, D. E., Hooke, K. F., Risley, E. A., Shen, T. Y., and Arman, C. G. (1977) Identification of the biologically active form of sulindac. $J$. Pharm. Exp. Ther. 201, 8-13

87. Thompson, H. J., Briggs, S., Paranka, N. S., Piazza, G. A., Brendel, K., Gross, P. H., Sperl, G. J., Pamukcu, R., and Ahnen, D. J. (1995) Inhibition of mammary carcinogenesis in rats by sulfone metabolite of sulindac. J. Natl. Cancer Inst. 87, 1259-1260

88. Piazza, G. A., Kulchak Rahm, A. L., Krutzch, M., Sperl, G., Paranka, N. S., Gross, P. H., Brendel, K., Burt, R. W., Alberts, D. S., Pamukcu, R., et al. (1995) Antineoplastic drugs sulindac sulfide and sulfone inhibit cell growth by inducing apoptosis. Cancer Res. 55, 31103116

89. Alberts, D. S., Hixson, L., Ahnen, D., Bogert, C., Einspahr, J., Paranka, N., Brendel, K., Gross, P. H., Pamukcu, R., and Burt, R. W. (1995) Do NSAIDs exert their colon cancer chemoprotective activities through inhibition of mucosal prostaglandin synthetase? J. Cell. Biochem., Suppl. 22, 18-23

90. Hanif, R., Pittas, A., Feng, Y., Koutsos, M. I., Qiao, L., Staiano-Coico, L., Shiff, S. I., and Riggs, B. (1996) Effects of nonsteroidal anti-inflammatory drugs on proliferation and induction of apoptosis in colon cancer cells by a prostaglandin-independent pathway. Biochem. Pharmacol. 52, 237-245

91. Carabaza, A., Cabré, F., Rotllan, E., Gómez, M., Gutiérrez, M., García, L., and Mauleón, D. (1996) Stereoselective inhibition of inducible cyclooxygenase by chiral nonsteroidal antiinflammatory drugs. J. Clin. Pharmacol. 36, 505-512

92. McCracken, J. D., Wechter, W. J., Liu, Y., Chase, R. L., Kantoci, D., Murray, E. D., Quiggle, D. D., Mineyama, Y. (1996) Antiproliferative effects of the enantiomers of flurbiprofen. J. Clin. Pharmacol. 36, 540-545

93. Abramson, S. B., and Weissmann, G. (1989) The mechanisms of action of antiinflammatory drugs. Arthritis Rheum. 32, 1-9

94. Fearon, E. R., and Vogelstein, B. (1990) A genetic model for colorectal tumorigenesis. Cell 61, 759-767

95. Bedi, A., Pasricha, P. J., Akhtar, A. J., Barber, J. P., Bedi, G. C., Giardiello, F. M., Zehnbauer, B. A., Hamilton, S. R., and Jones, R. J. (1995) Inhibition of apoptosis during development of colorectal cancer. Cancer Res. 55, 1811-1816 
96. Pasricha, P. J., Bedi, A., O’Connor, K., Rashid, A., Akhtar, A. J. Zahurak, M. L., Piantadosi, S., Hamilton, S. R., and Giardiello, F. M. (1995) The effects of sulindac on colorectal proliferation and apoptosis in familial adenomatous polyposis. Gastroenterology. 109, 994-998

97. Tsujii, M., and DuBois, R. N. (1995) Alterations in cellular adhesion and apoptosis in epithelial cells overexpressing prostaglandin endoperoxide synthase 2. Cell 83, 493-501

98. Kosaka, T., Miyata, A., Ihara, H., Hara, W., Sugimoto, T., Takeda, O. Takahashi, E., and Tanabe, T. (1994) Characterization of the human gene (PTGS2) encoding prostaglandin-endoperoxide synthase 2. Eur. J. Biochem. 221, 889-897

99. Tazawa, R., Xu, X.-M., Wu, K. K., and Wang, L.-H. (1994) Characterization of the genomic structure, chromosomal location, and promoter of human prostaglandin synthase-2 gene. Biochem. Biophys. Res. Commun. 203, 190-199

100. Kraemer, S. A., Arthur, K. A., Denison, M. S., Smith, W. L., and DeWitt, D. L. (1996) Regulation of prostaglandin endoperoxidase $H$ synthase-2 expression by 2,3,7,8-tetrachlorodibenzo-p-dioxin. Arch. Biochem. Biophys. 330, 319-328

101. Liu, Y., Levy, G. N., and Weber, W. W. (1996) Induction of human prostaglandin endoperoxide $\mathrm{H}$ synthase-2 (PHS-2) mRNA by TCDD. Prostaglandins 53, 97-107
102. Hague, A. Moorghen, M., Hicks, D., Chapman, M., and Paraskeva, C. (1994) BCL-2 expression in human colorectal adenomas and carcinomas. Oncogene 9, 3367-3370

103. Sano, H. Kawahito, Y., Wilder, R.L., Hashiramoto, A., Mukai, S., Kato, H., Kondo, M., and Hla, T. (195) Expression of cyclooxygenase-1 and 2 in human colorectal cancer. Cancer Res. 55, 3785-3789

104. Williams, C. S., Luongo, C., Radhika, A. Zhang, T., Lamps, L. W., Nanney, L. B., Beauchamp, R. D., and Dubois, R. N. (1996) Elevated cyclooxygenase2 levels in Min mouse adenomas. Gastroenterology 111, 1134-1140

105. Sherr, CJ. (1993) Mammalian Gl cyclins. Cell 73, 1059-1065

106. Goldberg Y., Nassif, I. I. Pittas, A., Tsai, L.-L., Dynlacht, B. D., Rigas B., and Shiff, S. J. (1996) The anti-proliferative effect of sulindac and sulindac sulfide on HT-29 colon cancer cells: alterations in tumor suppressor and cell cycle-regulatory proteins. Oncogene 12, 893-901

107. Kopp, E., and Ghosh, S. (1994) Inhibition of NF-B by sodium salicylate and aspirin. Science 265, 956-959

108. Arakawa, T., Oshima, T., Kishimoto, K., Yoshimoto, T., and Yamamoto, S. (1992) Molecular structure and function of the porcine arachidonate 12-lipoxygenase gene. J. Biol. Chem. 267, 12188-12191

109. Clària, J., and Serhan, C. N. (1995) Aspirin triggers previously undescribed bioactive eicosanoids by human endothelial cell-leukocyte interactions. Proc. Natl. Acad. Sci. USA 92, 9475-9579 